\title{
A concrete example
}

\author{
When the cracks begin to show.
}

\section{The Artistic Forms and Complexity Group: J.-P. Boon, J. Casti , C. Djerassi, J. Johnson, A. Lovett, T. Norretranders, V. Patera, C. Sommerer, R. Taylor and S. Thurner}

"You paid what? I have a chunk of the Berlin Wall at home that's at least as 'artistic' as this," sputtered Bill. "Did you leave your brain behind when you abandoned physics for finance? Putting a paving stone on a pedestal and calling it a work of art doesn't make it so, Dave. It's like writing down the alphabet and calling it the 'theory of everything."

"I stare at financial data all day long, watching the markets rise and fall," Dave replied. "I get paid to spot patterns in all of that craziness. I know the mathematics behind its complexity. But stocks aren't beautiful - not like that crack in the rock. Its complexity catches the eye. You're the art dealer, Bill; surely you can spot natural beauty." Bill shrugged: "I never said art and complexity were the same thing."

"Nanosculpture!" The gallery director had said. "Fill the biggest space in London with stuff so small you can't see it? Protein ready-mades! Very funny! I predict a dismal flop!"

Bill wasn't sure if they hadn't gone too far this time. Proposing an environmental installation on the beauty of nature might have been better. But didn't Dave pay $£ 100,000$ just for a piece of cement sculpture? An invisible nanosculpture for Piccadilly Circus! You can't beat the complexity of that! Isn't art about pushing the boundaries? To hell with beauty and logic!

The mood at the board meeting was explosive. Most members thought nanosculpture was a bad joke. But the director made clear that the goal of this seemingly absurd project was to trigger a mix of thoughts, emotions - even aggression - in the minds of millions of people. The invisible (and extremely expensive) nanosculpture would 'materialize' much more than any conventional work of art. With these dynamics, the piece could be sold as a complex system. Unfortunately, the director could not convince Dave, a complexity specialist, to verbalize this at the meeting. Following a day of sometimes hostile debate, no resolution was reached.

Dave left the meeting, wondering how to formalize his sensations. Beauty comes first, something I can see through a form. Why not say the complexity of this invisible sensation is virtually a nanosculpture, complex but invisible? Wouldn't this trigger mental processes equally well as the invisible nanosculpture? The most incredible phenomena in nature are invisible, but are mysterious works continually in progress. What about art? Is an invisible provocation enough? Isn't this the space of thought?

Bill's phone rang at an ungodly hour. He heard Dave mumble: "Janus."

"You mean Dionysus and Apollo?" Bill probed.

"No, art and science."

"Two faces looking in opposite directions?"

"But connected to the same device, a complex machine, actually."

"You mean art and science share the same...?"

"Yes, the same complexity," Dave said, abruptly hanging up.

Bill was at Heathrow, heading for New York. At the meeting in London, Dave crumbled, then whispered about some mystical nano-experience. Bill tried to contain his anxiety: could Dave work out his reaction to the nanosculpture project? The director was relying on him to persuade Dave to arbitrate between the factions on the board. But Dave's mind seemed to be splintering like that rock he'd installed in his living-room.

At the door, Bill found himself facing a woman in a white dress, no make-up, his own startled face reflected in mirrored sunglasses of the type he hated.

"I'm Bill," he stammered.

She cut him off: "Dave wants you to wait in this room," indicating a closed white door. "Make yourself comfortable," she said, and left him in a windowless all-white room: walls, ceiling, floor and a single piece of furniture: a white swivel stool. Even though the room was soundless, Bill soon felt a musiclike tinnitus ringing in his ears, something he'd never experienced before. But the most remarkable disturbance was visual. Everything around him was white. But the surfaces weren't smooth. The impression was a dynamic irregularity that made him wary. Rising from the stool, he slowly approached the facing wall, realizing that not even the faintest outline of a door was discernible. $\mathrm{He}$ must have dozed off, because suddenly he found himself looking up at Dave's face.

"Bill, your hour is up," he smiled.

"I've been here for an hour? I can't believe it."

"A full hour," said Dave. "Nano-art does that to you. Why don't you explain that to the director?"

Ultimately, Bill's power of persuasion had been so strong that he single-handedly brought the nano-installation into existence. But that was a year ago.

"It was entirely of your making," announced the director. "Now there's a bill to be paid. They've sued us for $£ 478,356,298$ for nano-vandalism." She went on to explain that he had unwittingly added a twist to the nanosculpture: the tiny self-reproducing protein had been engineered to mimic prion-like behaviour. Each time someone walked across Piccadilly Circus while thinking about the unbearable complexities of life, a protein molecule would make

a little crack in the stones in front of the person having the thought. Within weeks the entire pavement and many houses in the neighbourhood had cracked open completely. A spectacular work of art was now called Mad Cement Disease. "You will have to pay," the director explained. "But the suit does include VAT on the reconstruction costs. And you get to keep the stones. Perhaps Dave will buy them from you." This story is condensed from one created in the Japanese 'Renga' fashion by ten writers, each contributing one paragraph in sequence, with only the coordinator knowing the source of each paragraph. The authors were at a workshop on "Artistic Forms and Complexity", partially supported by the European Commission and organized by John Casti at the Wissenschaftszentrum Wien in Vienna in October 2005. The original story is at www.wzw.at/ file_upload/Kovacic_tmpphppCqC5Y.doc. 